https://doi.org/10.18778/1509-877X.2019.01.04

\title{
RAMy WeWnęTRZnego NADZORU PodatKowego, CZyli TAX CMS W POLSKIM WYDANIU
}

Streszczenie. Polski system prawa podatkowego doświadczył głębokich zmian wynikających z implementacji rekomendacji OECD/G20 (BEPS), dyrektyw unijnych oraz rodzimych polityk w zakresie tzw. uszczelniania systemu podatkowego. Doszło także do zaostrzenia kar finansowych dla przedsiębiorstw-podatników oraz sankcji karnych skarbowych dla osób je reprezentujących. Zwiększyła się też wykrywalność naruszeń, co bierze się m.in. z digitalizacji wymiany informacji, która pozwala na szybszy i głębszy wgląd w sytuację podatkową przedsiębiorstwa. W efekcie rośnie ryzyko podatkowe dla firm i ich przedstawicieli odpowiedzialnych za zgodność funkcji podatkowej z przepisami prawa (tax compliance). Tym samym coraz większego znaczenia nabiera potrzeba skutecznego mitygowania poszerzonego spektrum ryzyka. W największych organizacjach tworzy się w tym celu szczelne i całościowe procedury zarządzania ryzykiem podatkowym na zasadzie best practice, czyli fakultatywnie, ponieważ przepisy prawa nie obligują do tego. Polskie regulacje przewidują w szczególnych przypadkach jedynie ogólne obowiązki, np. zarządu spółki prawa handlowego w zakresie kontroli wewnętrznej niezbędnej dla zapewnienia prawidłowości rozliczeń podatkowych. Brak jednak wskazówek, jak taki system kontroli wewnętrznej w zakresie rozliczeń podatkowych miałby zostać skonstruowany.

Wzrost ryzyka podatkowego powoduje, że największe przedsiębiorstwa międzynarodowe sięgają po całościowe narzędzia do systemowego zarządzania funkcją podatkową. Dodatkowym i ważnym motywem implementacji narzędzia systemowego dla polskich firm okazał się Dział IIB. „Współdziałanie" ustawy Ordynacja podatkowa, który wszedł w życie z dniem 1 lipca 2020 r. Nowe przepisy umożliwiają największym przedsiębiorstwom zawarcie z Krajową Administracją Skarbową tzw. umowy o współdziałanie, dającej dostęp do wielu przywilejów, głównie w postaci braku kontroli podatkowych czy braku obowiązków MDR w odniesieniu do tzw. schematów krajowych. Aby zawrzeć

* Doktor nauk prawnych, partner zarządzający w TPA Poland, e-mail: wojciech. sztuba@tpa-group.pl 
umowę o współdziałanie, podatnik musi spełnić m.in. warunek wdrożenia tzw. Ram Wewnętrznego Nadzoru Podatkowego. Ministerstwo Finansów opublikowało projekt Wytycznych w zakresie Ram Wewnętrznego Nadzoru Podatkowego, opisujący wymagania takiego systemu, lecz bez wskazówek wykonawczych. To, co Ordynacja podatkowa nazywa Ramami Wewnętrznego Nadzoru Podatkowego, stanowi rozbudowany odpowiednik systemów typu Tax Compliance Management System, stosowanych w praktyce biznesowej wielu państw. Autor artykułu powołuje się na doświadczenia niemieckie, w RFN bowiem istnieje bogata doktryna i praktyka w zakresie tworzenia systemów typu Tax CMS opartych na standardzie audytorskim IDW PS 980 wprowadzonym przez Instytut Niemieckich Biegłych Rewidentów. Wdrożenie w polskich przedsiębiorstwach całościowego Tax CMS na podstawie przetestowanych rozwiązań zagranicznych może stanowić optymalny sposób zarządzania ryzykiem podatkowym w sytuacji, gdy rodzima praktyka zacznie się dopiero kształtować. Ponadto wdrożenie Tax CMS umożliwi spełnienie warunków zawarcia umowy o Współdziałanie, co dla wielu przedsiębiorstw i ich władz będzie stanowić pożądaną formę zabezpieczenia ryzyka wraz z uzyskaniem dodatkowych przywilejów.

Słowa kluczowe: program współdziałania, współdziałanie, monitoring horyzontalny, Ramy Wewnętrznego Nadzoru Podatkowego, Tax CMS, CMS, System Zarządzania Funkcją Podatkową, funkcja podatkowa, ryzyko podatkowe, zarządzanie ryzykiem podatkowym

\section{Wprowadzenie. Dynamika Ryzyka PODATKOWEgo}

Obszar związany z rozliczaniem zobowiązań podatkowych (tax compliance) należy do krytycznych funkcji administracyjnych w każdym przedsiębiorstwie. Choć z ryzykiem podatkowym firmy i ich zarządy zmagają się od zawsze, ostatnie lata przyniosły wiele nowych okoliczności powodujących systematyczny wzrost ryzyka podatkowego prowadzenia działalności. Należy przez to rozumieć zarówno rosnące prawdopodobieństwo stwierdzenia naruszeń (także nieintencjonalnych) w warunkach coraz bardziej złożonych i niejednoznacznych przepisów prawa, jak i wzrost dotkliwości kar z tym związanych. W tym kontekście przedsiębiorstwa i osoby nimi zarządzające stają w obliczu rosnącego zagrożenia karami finansowymi (dla firmy) oraz finansowymi i pozafinansowymi w myśl przepisów Kodeksu karnego skarbowego ${ }^{1}$ (dla członków zarządu i innych osób). Nawet drobne błędy mogą prowadzić do wszczęcia postępowania karnego skarbowego kończącego się prawomocnym skazaniem. W roku 2020 uszczuplenie należności publicznoprawnej w kwocie wyższej niż 13 tys. zł jest ścigane jako przestępstwo skarbowe $e^{2}$. Tak niska suma zależy od wartości minimalnego wynagrodzenia brutto, za to zupełnie abstrahuje od skali działania firmy

1 Ustawa z dnia 10 września 1999 r. Kodeks karny skarbowy (Dz.U. Nr 83, poz. 930 ze zm., w brzmieniu obowiązującym na dzień 1.06.2020 r. (dalej: k.k.s.).

${ }^{2}$ Artykuł $53 \$ 3$ k.k.s., w powiązaniu z obowiązującym od stycznia 2020 r. minimalnym wynagrodzeniem brutto w wysokości 2600 zł. 
i powoduje, że wraz ze wzrostem organizacji silnie rośnie ryzyko wystąpienia zaległości podatkowej powyżej tego limitu.

Praktyczne konsekwencje skazania za przestępstwo skarbowe rzadko polegają na pozbawieniu lub ograniczeniu wolności (choć jest to możliwe), w powszechnym użytku jest natomiast kara grzywny, która jest mnożnikiem (od 10 do 720) tzw. stawek dziennych (od 1/30 do 400-krotności minimalnego wynagrodzenia). W efekcie kara grzywny za przestępstwo skarbowe może wynieść od 866,70 zł aż do 24960960 zł. Niemniej nawet przy stosunkowo niewysokich karach grzywny skutki prawne skazania mogą się okazać daleko idące i oznaczać np. utratę uprawnień zawodowych lub prawa do zasiadania w organach spółek. Warto przy tym dodać, że istniejąca w polskim k.k.s. instytucja dobrowolnego poddania się odpowiedzialności, dzięki której można, regulując zaległy podatek z odsetkami i uzgodnioną $\mathrm{z}$ organem ścigania karą pieniężną, uniknąć formalnego skazania, nie jest dostępna dla przestępstw zagrożonych karą wolnościową. Te zaś dotyczą m.in. uszczupleń należności publicznoprawnych przekraczających kwotę $1300000 \mathrm{zł}^{3}$.

Niezależnie od powyższych uwag na temat regulacji związanych z występowaniem naruszeń prawa podatkowego radykalnie zwiększa się także sama ich wykrywalność. Wynika to m.in. z digitalizacji wymiany informacji, umożliwiającej władzom skarbowym szybki i głęboki wgląd w sytuację gospodarczą podatników i wykorzystywanie tworzącego się zasobu big data, np. poprzez statystyczne analizy porównawcze, międzyokresowe (w ramach jednego podatnika) czy sektorowe.

Trzeba przy tym wskazać, że ryzyko podatkowe zarówno w zakresie regulacji materialnoprawnych, jak i obiektywnej wykrywalności nadużyć rośnie nie tylko w Polsce. W związku $\mathrm{z}$ tendencją do zaostrzania norm związanych $\mathrm{z}$ zapobieganiem erozji bazy podatkowej i unikaniem opodatkowania, zainicjowanych przez OECD/G20 w tzw. pakiecie BEPS (Base Erosion and Profit Shifting) w 2013 r. ${ }^{4}$, można mówić o trendzie globalnym, w szczególności obejmującym państwa wysoko rozwinięte i rozwijające się. Po niecałych siedmiu latach niemal wszystkie spośród piętnastu rekomendowanych w BEPS działań głęboko redefiniujących normy prawa podatkowego stanowią dziś element składowy zarówno

3 Tak zwana duża wartość w trybie art. $53 \$ 15$ k.k.s., w powiązaniu z art. $17 \$ 2$ i art. $37 \$ 1$ k.k.s.

${ }^{4}$ Szerzej: Action Plan on Base Erosion and Profit Shifting, OECD Publishing, Paris 2013. 
obowiązującego prawa wspólnotowego Unii Europejskiej (UE), jak i prawa krajowego licznych państw, w tym Polski. Są też źródłem wielu zupełnie nowych typów obowiązków oraz rodzą nieznane wcześniej rodzaje ryzyka dla firm i ich zarządów, a także koszty związane z zapewnieniem zgodności (compliance).

\section{Systemy CaŁościowego ZaRzĄDZANia FUnKCJĄ PODATKOWĄ}

OD BEST PRACTICE DO STANDARDU MINIMUM

W duchu opisanych zmian rośnie presja różnego typu interesariuszy na zarządy firm i rady nadzorcze w zakresie skutecznego mitygowania poszerzonego spektrum ryzyka. W największych organizacjach tworzy się szczelne i całościowe procedury zarządzania ryzykiem podatkowym na zasadzie best practice, czyli fakultatywnie. Niemniej dostrzega się też trend do głębszego uregulowania tego zagadnienia bądź to w statutach korporacyjnych, bądź to - w niektórych państwach - także w standardach profesjonalno-zawodowych, np. standardach audytu finansowego ${ }^{5}$. W Polsce przepisy prawa ujmują ten obszar, jak dotąd, zdawkowo. Przykładowo, ustawa o rachunkowości ${ }^{6}$ nakłada na zarząd spółki prawa handlowego odpowiedzialność za kontrolę wewnętrzną niezbędną dla prawidłowego sporządzenia sprawozdania finansowego, obejmującego również prawidłowość rozliczeń podatkowych, a na radę nadzorczą odpowiedzialność za nadzorowanie procesu sprawozdawczości finansowej ${ }^{7}$. Z kolei w jednostkach zainteresowania publicznego (JZP), czyli np. spółkach giełdowych, ustawa o biegłych rewidentach przewiduje dodatkowe obowiązki rady nadzorczej (komitetu audytu) w zakresie monitorowania skuteczności systemów kontroli wewnętrznej i systemów zarządzania ryzykiem, w tym w obszarze podatkowym ${ }^{8}$. Podobne regulacje pojawiają się zarówno w przepisach

${ }^{5}$ Na przykład w Republice Federalnej Niemiec podstawą tworzenia kompleksowych systemów typu Compliance Management (CMS) w obszarze podatkowym jest standard Instytutu Niemieckich Biegłych Rewidentów nr IDW PS 980 (por. przyp. 21).

${ }^{6}$ Ustawa z dnia 29 września 1994 r. o rachunkowości (Dz.U. Nr 121, poz. 591 ze zm., w brzmieniu obowiązującym na dzień 1 czerwca 2020 r.).

7 Artykuł 4a oraz art. 24 ust. 4 pkt 3 ustawy o rachunkowości.

8 Artykuł 130 ust. 1 pkt 1 Ustawy z dnia 11 maja 2017 r. o biegłych rewidentach, firmach audytorskich i nadzorze publicznym (Dz.U. poz. 1089 ze zm., w brzmieniu obowiązującym na dzień 1 czerwca 2020 r.). 
wspólnotowych ${ }^{9}$, jak i amerykańskich ${ }^{10}$, w związku z czym dotyczą polskich spółek zależnych od jednostek notowanych na giełdach w UE i Stanach Zjednoczonych. Znajdziemy je także w polskich wytycznych odnoszących się do spółek notowanych na Giełdzie Papierów Wartościowych w Warszawie ${ }^{11}$ czy zaleceniach dla sektora finansowego uchwalanych przez Komisję Nadzoru Finansowego ${ }^{12}$. Niezależnie od powyższego przytoczone normy dotyczące polskich firm nie wykraczają poza ogólnikowe określenie obowiązków i odpowiedzialności za ich dochowanie, milczą zaś co do tego, jak taki system kontroli wewnętrznej w zakresie rozliczeń podatkowych ma w praktyce zostać skonstruowany.

\section{Nowe PRZEPISY o tZW. WspóŁDZIAŁANIU,} CZYLI MONITORING HORYZONTALNY

Zanim przejdziemy do rozważań dotyczących skutecznego i kompleksowego systemu zarządzania funkcją podatkową, należy wymienić jeszcze jeden ważny powód, który może uzasadniać wdrożenie takiego systemu. Poza opisanymi wyżej powodami wynikającymi z ryzyka podatkowego dla przedsiębiorstwa i osób nim zarządzających istotnym motywem implementacji narzędzia systemowego może się okazać tzw. monitoring horyzontalny. Rodzima wersja monitoringu horyzontalnego pojawiła się w naszym porządku prawnym z dniem 1 lipca 2020 r. jako dział IIB. „Współdziałanie” ustawy Ordynacja podatkowa ${ }^{13}$.

${ }^{9}$ Dyrektywa Parlamentu Europejskiego i Rady (UE) nr 2014/56/UE (https://eur-lex. europa.eu/legal-content/PL/TXT/HTML/?uri=CELEX:32014L0056\&from=PL) oraz Rozporządzenie Parlamentu Europejskiego i Rady (UE) nr 537/2014 (https://eur-lex.europa.eu/ legal-content/PL/TXT/HTML/?uri=CELEX:32014R0537\&from=PL).

${ }^{10}$ Ustawa kongresu Stanów Zjednoczonych „Sarbanes-Oxley-Act” z dnia 30 lipca 2002 r., Washington.

11 A. S. Nartowski, Dobre Praktyki Spółek Notowanych na GPW 2016, GPW, Warszawa 2016, https://www.gpw.pl/pub/GPW/files/PDF/Podrecznik_DPSN_2016_9_03_16. pdf (dostęp: 1.10.2020).

12 Urząd Komisji Nadzoru Finansowego, Rekomendacje dotyczace funkcjonowania Komitetu Audytu, KNF, Warszawa 2010, https://www.knf.gov.pl/knf/pl/komponenty/img/ Rekomendacje-komitet_audytu.pdf (dostęp: 1.10.2020).

13 Ustawa z dnia 29 sierpnia 1997 r. Ordynacja podatkowa (tekst jedn. Dz.U. 2020, poz. 1325), dalej: o.p. Artykuły od 20s do 20zr o.p. w brzmieniu obowiązującym od dnia 1 lipca $2020 \mathrm{r}$. 
Koncepcja monitoringu horyzontalnego pochodzi jeszcze $\mathrm{z}$ epoki sprzed BEPS, kiedy to transparentność i oparta na wzajemnym zaufaniu i wymianie informacji relacja podatnika $\mathrm{z}$ administracją skarbową była początkowo testowana $\mathrm{w}$ takich państwach jak Holandia ${ }^{14}$. Do tej pory monitoring horyzontalny przeszedł testy pilotażowe w wielu państwach, m.in. w Austrii, Francji, Hiszpanii, Australii czy Stanach Zjednoczonych. Z kolei odkąd BEPS zaczął odciskać swoje głębokie piętno na systemie międzynarodowego prawa podatkowego, idea transparentności przesunięta została na kolejny, wyższy poziom. I to już nie tyle w atmosferze wzajemnego zaufania, stanowiącej paradygmat monitoringu poziomego przed BEPS, co raczej $\mathrm{z}$ naciskiem na jednostronną transparentność, czyli pełną jawność sytuacji podatnika dla władz. Taki skutek niesie za sobą m.in. Działanie nr 12 BEPS, w wyniku którego na terytorium UE, a w Polsce najwcześniej i najszerzej, wprowadzono powszechny mechanizm raportowania tzw. schematów podatkowych przez podatników oraz ich doradców (Mandatory Disclosure Rules - MDR).

W okresie post-BEPS, tj. m.in. w warunkach daleko idących obowiązków MDR i dotkliwych kar związanych z ich naruszeniem, wprowadzenie monitoringu horyzontalnego do polskiego porządku prawnego zyskuje nieco inny wymiar. Poprzez przystąpienie do Współdziałania transparentność podatnika nie zwiększy się bowiem radykalnie (bo już jest wysoka), natomiast w zależności od praktyki funkcjonowania Współdziałania korzyści z nim związane mogą się okazać atrakcyjne dla wielu przedsiębiorstw i członków ich władz. Nowe przepisy Ordynacji podatkowej stworzą największym przedsiębiorstwom możliwość zawarcia z Krajową Administracją Skarbową (KAS) tzw. umowy o współdziałanie w zakresie podatków. Będzie to umowa cywilnoprawna, której podpisanie będzie się wiązać $\mathrm{z}$ wieloma specjalnymi przywilejami, głównie w postaci braku kontroli podatkowych (choć nadal prowadzone będą kontrole celno-skarbowe), braku obowiązków MDR w odniesieniu do tzw. schematów krajowych czy (w pewnych warunkach) ograniczenia niektórych sankcji, m.in. w podatku VAT. Aby zawrzeć umowę o współdziałanie, przedsiębiorstwo musi jednak spełnić kilka warunków, m.in. wykazać za ostatni rok podatkowy przychody nie niższe niż równowartość 50 mln euro oraz uzyskać pozytywną

14 The Netherlands Tax and Customs Administration, Horizontal Monitoring Guide, Version 1.0, Amsterdam 2010, s. 7, https://download.belastingdienst.nl/belastingdienst/docs/ horizontal_monitoring_very_large_businesses_dv4061zlpleng.pdf (dostęp: 1.10.2020). 
opinię KAS na podstawie audytu wstępnego za okres dwóch ostatnich lat podatkowych. Przede wszystkim jednak firma musi wdrożyć tzw. Ramy Wewnętrznego Nadzoru Podatkowego, co zgodnie z brzmieniem przepisu art. 20u ust. 2 o.p. oznacza posiadanie „skutecznego i adekwatnego zbioru zidentyfikowanych i opisanych procesów oraz procedur dotyczących zarządzania wykonywaniem obowiązków wynikających z przepisów prawa podatkowego”. Z przepisów nie wynika, że wdrożenie „ram” jest wymagane przed zawarciem umowy z KAS, ale konstrukcja systemu podlega weryfikacji już na etapie audytu wstępnego poprzedzającego zawarcie umowy.

\section{Ramy Wewnętrznego Nadzoru Podatkowego}

Choć Ordynacja podatkowa nie precyzuje, w jaki sposób takie „ramy” lub „zbiór” mają zostać zorganizowane, niedawno Ministerstwo Finansów opublikowało Wytyczne w zakresie Ram Wewnętrznego Nadzoru Podatkowego $^{15}$. W tym dokumencie znajduje się długa lista szczegółowych wymagań stawianych takiemu systemowi, lecz bez wskazówek wykonawczych. Podatnicy zainteresowani zawarciem $\mathrm{z}$ władzami podatkowymi umowy o współdziałaniu będą zobowiązani stworzyć system do zarządzania rozliczeniami podatkowymi odpowiadający wymaganiom Ram Wewnętrznego Nadzoru Podatkowego, zanim wystąpią o zawarcie takiej umowy.

Treść Wytycznych Ministerstwa Finansów dowodzi, że stworzenie Ram nie będzie zadaniem łatwym: Ramy mają obejmować i szczegółowo opisywać takie obszary, jak: strategia podatkowa przedsiębiorstwa, ład podatkowy, system zarządzania ryzykiem podatkowym, system zarządzania kadrami i odpowiedzialnością w zakresie funkcji podatkowej, zarządzanie dokumentacją i systemy informatyczne. Wiele z tych pojęć pojawia się po raz pierwszy w polskim obszarze regulacyjnym. Dotyczy to np. pojęcia „ład podatkowy”, które Wytyczne na kilku stronach rozwijają. Ład podatkowy ma być częścią ładu korporacyjnego i obejmować „określenie zadań, ról, uprawnień, obowiązków i odpowiedzialności w zakresie kwestii podatkowych oraz opis funkcji podatkowej, w tym struktury komórki odpowiedzialnej za prawidłowość wypełniania obowiązków podatkowych"16.

15 Wytyczne w zakresie Ram Wewnętrznego Nadzoru Podatkowego (wersja 2.0. zczerwca 2020 r.), Warszawa 2020, https://www.podatki.gov.pl/media/6197/wytycznew-zakresie-ram-wewn\%C4\%99trznego-nadzoru-podatkowego.pdf (dostęp: 1.10.2020).

16 Ibidem, s. 10. 
Mówimy zatem o konieczności stworzenia w przedsiębiorstwie rozbudowanych struktur pojęciowo-funkcjonalnych, wcześniej na ogół nieregulowanych, i powiązania ich $\mathrm{z}$ innymi strukturami, często także stanowiącymi novum. Na przykład ład podatkowy musi oprócz powiązania z (a) ładem korporacyjnym wykazać również osadzenie w (b) „strategii podatkowej”, (c) „polityce podatkowej” i (d) „polityce kontroli dokumentacji i procesów podatkowych" przedsiębiorstwa, przy czym każda z nich musi zostać należycie udokumentowana i zoperacjonalizowana ${ }^{17}$.

W wyniku wdrożenia Ram przedsiębiorstwo musi mieć udokumentowane procedury związane $\mathrm{z}$ audytem i kontrolą wewnętrzną, zarządzaniem ryzykiem podatkowym i w zakresie realizacji wszystkich funkcji związanych ze zgodnością. Co więcej, oczekuje się, że Ramy zostaną $\mathrm{w}$ wysokim stopniu zintegrowane $\mathrm{z}$ funkcjami związanymi z rolą organów nadzorczych i zarządzających firmy, niepodatkowymi działami operacyjnymi, w tym HR i IT, obsługą klientów i dostawców, a także z komunikacją $\mathrm{z}$ władzami podatkowymi. Wytyczne zawierają rozbudowane wymagania co do wymienionych elementów konstrukcji, zakresu regulacji i sposobu realizacji oraz okresowego kontrolowania Ram Wewnętrznego Nadzoru Podatkowego, aby mogły one zostać uznane za „skuteczne i adekwatne”, co stanowi warunek Współdziałania. Przykładowo, w zakresie elementu konstrukcji Ram, jakim jest system zarządzania ryzykiem podatkowym, wytyczne określają, że powinien on zostać zbudowany z takich komponentów, jak ustalenie celów, identyfikacja ryzyka, ocena ryzyka, informacja i komunikacja oraz kontrola i monitorowanie. Przy tym np. element oceny i identyfikacji ryzyka ma zostać skonstruowany na podstawie ustalonego dla danej organizacji tzw. apetytu na ryzyko, czyli maksymalnego poziomu ryzyka, jakie firma jest w stanie zaakceptować dla realizacji swoich celów. Wytyczne nie mówią już jednak, jak w bezpieczny dla przedsiębiorstwa sposób określić niezerowy apetyt na ryzyko. Ten i wiele innych fragmentów Wytycznych dowodzi, że stworzenie Ram Wewnętrznego Nadzoru Podatkowego w taki sposób, aby uzyskać korzyści ze Współdziałania, bez jednoczesnego wejścia na ścieżkę maksymalizacji efektywnego opodatkowania biznesu oraz bez olbrzymiego wzrostu kosztów administracyjnych wynikających z silnie zbiurokratyzowanego modelu Współdziałania, nie będzie zadaniem trywialnym.

\footnotetext{
17 Ibidem, s. 8-22.
} 
To, co Ordynacja podatkowa nazywa Ramami Wewnętrznego Nadzoru Podatkowego, stanowi rozbudowany odpowiednik tzw. Systemu Zarządzania Zgodnością w obszarze podatków ( Tax Compliance Management System - Tax CMS), którego różne wersje są, w niektórych przypadkach od dawna, stosowane w praktyce biznesowej wielu państw. Na potrzeby opracowania przeanalizowano doświadczenia niemieckie, jako stanowiące ważny punkt odniesienia dla polskiej gospodarki, także poprzez znaczny udział polskich firm z kapitałem niemieckim, z których część stosuje rozwiązania koncernowe typu Tax CMS. W RFN nie wdrożono dotąd rozwiązań dotyczących monitoringu horyzontalnego, dlatego bogata praktyka implementacji Tax CMS zasadza się nie na przywilejach, lecz na skutecznym zarządzaniu ryzykiem podatkowym. Podobnie jak w Polsce, obowiązujące w Niemczech przepisy prawa podatkowego nie obligują podatników do posiadania Tax CMS, czyli całościowego systemu zarządzania zgodnością w obszarze podatków ${ }^{18}$. I podobnie jak u nas, obowiązują zbliżone regulacje z poziomu nadzoru jednostek zainteresowania publicznego, czyli przepisy obligujące organy statutowe spółek do utrzymywania skutecznych systemów nadzoru i kontroli wewnętrznej w sprawach podatkowych. Konstrukcyjne szczegóły w zakresie opracowania znormalizowanego Tax CMS oferuje dopiero standard audytorski IDW PS 980, wprowadzony przez Instytut Niemieckich Biegłych Rewidentów ${ }^{19}$. Standard PS 980 nie dotyczy wyłącznie podatkowych Systemów Zarządzania Zgodnością, lecz także zuniwersalizowanych zasad tworzenia i audytu systemów zarządzania zgodnością różnych obszarów wymagających kontroli zgodności regulacyjnej (compliance). $\mathrm{Na}$ jego podstawie w Niemczech ukształtowała się bogata i wieloletnia doktryna oraz praktyka w zakresie wymogów, jakie powinien spełniać podatkowy system zarządzania zgodnością, czyli Tax CMS. Co więcej, choć początkowo Tax CMS był zwyczajowo rozwiązaniem dedykowanym przedsiębiorstwom dużym, ze względu na łatwość adaptacji, rozszerzeń i skalowania

${ }_{18}$ W. Niemann, P. Dodos, Tax Compliance Management System. Regelungen und Arbeitshilfen, München 2019, s. 2.

19 Standard Instytutu Niemieckich Biegłych Rewidentów (Institut Deutscher Wirtschaftsprüfer) nr IDW PS 980 pt. Wytyczne prawidłowego badania Systemów Zarządzania Zgodnością (Grundsätze ordnungsmäßiger Prüfung von Compliance Management Systemen), https://www.idw.de/idw/verlautbarungen/idw-ps-980/43124 (dostęp: 1.10.2020). 
adekwatnie do indywidualnego profilu ryzyka, obecnie upowszechnia się również wśród niemieckich firm średniej wielkości ${ }^{20}$.

Przedstawienie szczegółowych założeń niemieckiego modelu Tax CMS wykracza poza ramy niniejszego opracowania. Należy jednak podkreślić, że model ten dobrze nadaje się do zaadaptowania do polskich warunków regulacyjnych i z powodzeniem może służyć potrzebom polskich przedsiębiorców. Wynika to stąd, że kalibracja regulacyjna, czyli dostosowująca Tax CMS do realizacji obowiązków wynikających z polskiego prawa podatkowego, mieści się w obszarze ustawień miękkich systemu, podczas gdy jego konstrukcja procesowa (m.in. w zakresie mapowania ryzyka, kontroli procesów rozliczeniowych i sprawozdawczych, obiegu dokumentów, obiegu autoryzacji, kontroli wewnętrznej etc.) to obszar zarządczy, który zachowuje uniwersalną wartość niezależnie od lokalnego systemu prawa.

\section{WNIOSKI}

Wdrożenie w polskich przedsiębiorstwach całościowego Tax CMS, który z braku rodzimych doświadczeń warto zbudować na podstawie przetestowanych rozwiązań zagranicznych, istotnie poprawi bezpieczeństwo prawne zarówno firmy, jak i jej władz. Po pierwsze, nawet przy wystąpieniu nieprawidłowości wykrytych $\mathrm{w}$ toku kontroli znacznie obniży się ryzyko zarzutu nienależytej staranności, która w prawie karnym skarbowym jest uznawana za wystarczającą przesłankę winy umyślnej umożliwiającej ściganie przestępstw skarbowych. Po drugie, posiadanie Tax CMS umożliwi spełnienie warunków zawarcia umowy o Współdziałanie, co dla wielu przedsiębiorstw i ich władz będzie stanowić pożądaną formę zabezpieczenia ryzyka wraz z uzyskaniem dodatkowych przywilejów. W takim przypadku, tj. gdy jednym z celów przedsiębiorstwa jest zawarcie umowy o Współdziałanie, Tax CMS musi dodatkowo zostać skonfigurowany w sposób zgodny z wymogami dotyczącymi skutecznych i adekwatnych Ram Wewnętrznego Nadzoru Podatkowego.

20 W. Niemann, P. Dodos, Tax Compliance..., s. 3. 


\section{BIBLIOGRAFIA}

Action Plan on Base Erosion and Profit Shifting, OECD Publishing, Paris 2013. Institut Deutscher Wirtschaftsprüfer, IDW PS 980 Grundsätze ordnungsmäßiger Prüfung von Compliance Management Systemen, IDW, Düsseldorf 2011, https://www.idw.de/ idw/verlautbarungen/idw-ps-980/43124 (dostęp: 1.10.2020).

Ministerstwo Finansów RP, Wytyczne w zakresie Ram Wewnętrznego Nadzoru Podatkowego (wersja 2.0. z czerwca 2020 r.), Warszawa 2020, https://www.podatki. gov.pl/media/6197/wytyczne-w-zakresie-ram-wewn\%C4\%99trznego-nadzorupodatkowego.pdf (dostęp: 1.10.2020).

Nartowski A. S., Dobre Praktyki Spółek Notowanych na GPW 2016, GPW, Warszawa 2016, https://www.gpw.pl/pub/GPW/files/PDF/Podrecznik_DPSN_2016_9_03_16.pdf (dostęp: 1.10.2020).

The Netherlands Tax and Customs Administration, Horizontal Monitoring Guide, Version 1.0, Amsterdam 2010, https://download.belastingdienst.nl/belastingdienst/ docs/horizontal_monitoring_very_large_businesses_dv4061zlpleng.pdf (dostęp: 1.10.2020).

Niemann W., Dodos P., Tax Compliance Management System. Regelungen und Arbeitshilfen, München 2019.

Urząd Komisji Nadzoru Finansowego, Rekomendacje dotyczace funkcjonowania Komitetu Audytu, KNF, Warszawa 2010, https://www.knf.gov.pl/knf/pl/komponenty/img/ Rekomendacje-komitet_audytu.pdf (dostęp: 1.10.2020).

\section{Internal Tax Supervision Framework. Polish regulatory attempt TO TAX CMS}

Summary. Polish tax system has experienced deep regulatory changes resulting from OECD/G20 recommendations (BEPS), EU law impact and local policies aiming at anti-avoidance. Also, the level of penalisation has increased both for enterprises and their representatives. On the other hand, the detectability of tax arrears has sharply been raised due to digital information technologies that allow higher transparency and fasted insight into taxpayers' situation. As a result, the tax exposure is significantly higher now, both for corporates and persons in charge for tax compliance. The need to efficiently mitigate the extended tax risk spectrum is therefore higher than ever. In the largest organisations complex tax risk management structures are created as a best practice i.e. non mandatory. Polish law sets forth only general duties e.g. for the management board of the companies to assure internal control necessary to provide proper financial reporting including tax. Precise indices o how to build such internal tax control system are missing.

Raising tax exposure motivates MNE's to reach out to complex tax compliance management tools. An additional and important reason for Polish firms to do so may become the new Chapter IIB. Co-operation of the Polish Tax Ordinance Act that is going to enter into force on July $1^{\text {st }}$. These new horizontalmonitoring-regulations allow the largest companies to conclude the Co-operation Agreement with Polish tax administration, as a result of which a list of tax benefits may be enjoyed, such as lack of tax inspections or no DAC-6 duties (mandatory disclosure) on local arrangements. In order to close such an agreement tax payers will have to fulfil inter alia a condition to implement the so-called Internal Tax Control Framework. The Ministry of Finance recently published the remarks on such a Framework and what kind of criteria must it meet, but without indices on how to execute it. 
What the Tax Ordinance Act calls Internal Tax Control Framework represents a kind of Tax Compliance Management System, many of which have broadly been used in foreign jurisdictions so far. Author of the article is making reference to German experiences, as in Germany there is an extensive doctrine and business practice in place, as regards implementation of Tax CMS based on audit standard IDW PS 980 published by German Institute of Chartered Accountants. Implementing Tax CMS in Polish firms in reliance on well tested foreign standards may constitute an optimal way to manage tax exposure in times when our local practice has yet to start to be accumulated. Moreover, adopting Tax CMS in such form shall enable to meet the conditions to close the Co-operation Agreement that besides better tax safety offers also additional benefits.

Keywords: horizontal monitoring, Internal Tax Supervision Framework, Tax CMS, CMS, tax compliance, tax compliance management, tax risk, tax risk management, tax compliance management system 